Vol. 14 | No. 1 |65-73| January - March | 2021 ISSN: 0974-1496 | e-ISSN: 0976-0083 | CODEN: RJCABP http://www.rasayanjournal.com http://www.rasayanjournal.co.in

\title{
THE EFFECT OF ETHANOL EXTRACT AND ETHYL ACETIC FRACTION OF STANDARDISED CHAYOTE SQUASH TO REDUCE BLOOD SUGAR LEVEL AND THE FUNCTION OF PANCREATIC ß-CELL OF MALE ALBINO RATS INDUCED BY STZ-NA-HFD
}

\author{
Jekson Martiar Siahaan ${ }^{1,2, \bowtie}$, Syafruddin Illyas $^{3}$, Dharma Lindarto ${ }^{4}$ \\ and Marline Nainggolan ${ }^{5}$ \\ ${ }^{1}$ Doctoral Program, Universitas Sumatera Utara, Medan, Indonesia \\ ${ }^{2}$ Department of Physiology, Faculty of Medicine, Universitas Methodist Indonesia, Medan, \\ Indonesia \\ ${ }^{3}$ Department of Biology, Faculty of Mathematics and Natural Science, Universitas Sumatera \\ Utara, Medan, Indonesia \\ ${ }^{4}$ Department of Internal Medicine, Faculty of Medicine, Universitas Sumatera Utara, Medan, \\ Indonesia \\ ${ }^{5}$ Department of Pharmaceutical Biology, Faculty of Pharmacy, Universitas Sumatera Utara, \\ Medan, Indonesia \\ ${ }^{{ }^{\circledR}}$ Corresponding Author: jekson.siahaan.sked@gmail.com
}

\begin{abstract}
An impaired pancreatic $\beta$-cell function can cause glucotoxicity, measured by the homeostasis model assessment of $\beta$ cell function (HOMA-B). Glucotoxicity can be controlled by administering extracts and fractions of plant secondary metabolite compounds that are anti-hyperglycemic and preventing damage to pancreatic $\beta$-cells. This study was conducted to evaluate the effect of ethanol extract and ethyl acetate fraction of chayote squash on the function of pancreatic $\beta$-cells and the decrease of blood glucose levels. Dry chayote squash was characterized, extracted with ethanol, and fractionated with ethyl acetate. The experimental albino rats were administered with streptozotocin, nicotinamide, and high-fat diets for up to 72 hours. After an increase in blood glucose levels, albino rats were treated with ethanol extract and ethyl acetate fraction by post-test randomized controlled group design for one month. After the treatment, the blood glucose level and insulin level were tested. Homeostasis model assessment of insulin resistance (HOMA-IR) was applied. Simplified characteristics of the chayote squash were following the standards of herbal medicines in Indonesia. Chayote squash ethanol extract had a high total phenolic content, while the ethyl acetate fraction had a high total flavonoid content. Giving ethanol extract at a dose of $100 \mathrm{mg} / \mathrm{kg}$ bw could increase insulin secretion and HOMA-B to a higher degree. Meanwhile, ethyl acetate fraction at a dose of $100 \mathrm{mg} / \mathrm{kg}$ bw could reduce blood glucose levels. It is concluded that the administration of ethanol extract and ethyl acetate fraction of chayote squash can maintain the function of pancreatic $\beta$-cells and lower blood glucose levels.
\end{abstract}

Keywords: Chayote Squash, Secondary Metabolites, Anti-hyperglycemia, Pancreatic ß-cells, Insulin, HOMA-IR

RASĀYAN J. Chem., Vol. 14, No.1, 2021

\section{INTRODUCTION}

Diabetes mellitus (DM) is one of some endocrinology diseases characterized by chronic hyperglycemia and impaired carbohydrate, protein, and fat metabolism due to abnormal insulin secretion, insulin action, or both. Persistent hyperglycemia is associated with long-term complications, dysfunction, and failure of various organs. ${ }^{1,2}$

Diabetes Mellitus Type 2 is progressive due to a combination of multifactorial factors, including the environment and genetics that induces insulin resistance and pancreatic $\beta$-cell dysfunction. Two pathomechanisms of DM are pancreatic $\beta$-cell dysfunction and insulin resistance. ${ }^{3-6}$ Pancreatic $\beta$-cell 
dysfunction interferes with insulin secretion so that the decrease in blood glucose is disrupted. ${ }^{3,4}$ Although the mechanism underlying pancreatic $\beta$-cell dysfunction is not yet fully known but could be caused by multifactorial factors such as genetic, environmental factors (malnutrition and obesity), and metabolic disorders (insulin resistance, lipotoxicity, and inflammation). Pancreatic B-cell dysfunction can be measured using the homeostasis model assessment of $\beta$-cell function (HOMA-B). ${ }^{7}$

Modeling type 2 diabetes mellitus in experimental animals can be done by inducing male albino rats using streptozotocin (STZ), nicotinamide (NA), and high-fat diets (HFD). STZ forms free radicals such as reactive oxygen species (ROS) and reactive nitrogen species (RNS) in the mitochondria, causing dephosphorylation of Adenosine triphosphate (ATP). Some free radicals are the leading cause of pancreatic ß-cell damage. Still, pancreatic B-cell damage can be temporary because it can regenerate gradually and inhibit excessive apoptosis and excessive glucagon secretion. ${ }^{8-11}$ The administration of nicotinamide may partially inhibit the damage of pancreatic $\beta$-cell damage as it acts as a cytoprotective agent to pancreatic $\beta$ cells. ${ }^{12,13}$ Meanwhile, the administration of HFD was intended to increase rat weight and trigger insulin resistance. ${ }^{14}$

The traditional medicine from plants is an optional treatment for several types of diseases, including diabetes mellitus. Shrinker, which is characterized by an increase in blood glucose levels, can be controlled by natural ingredients containing flavonoids, one of which is chayote squash. The pharmacological effects of this fruit are cardioprotective, anti-diabetic, anti-obesity, antioxidant, anti-inflammatory, anti-ulcer, anticancer, anti-mutagenic, antimicrobial, anti-epileptic, and hepatoprotective. ${ }^{15-17}$ This research was conducted to determine the effect of ethanol extract and chayote squash on the function of pancreatic B-cells and the potential reduction in blood glucose levels in vivo.

\section{Materials}

\section{EXPERIMENTAL}

The material used in this research is the chayote squash obtained from Sidamanik District, Indonesia. The experimental animals used in this study were three months old albino rats with a bodyweight of 150-220 g, which had been acclimated for one week. The chemicals used were pro analysis quality (Merck), iron (III) chloride reagents, Bouchardat, Dragendorf, Liebermann-Burchard, Meyer, Molisch, zinc and magnesium powders, Folin-Ciocalteu reagents, quercetin, gallic acid, aqua distillate, quail egg yolks, coconut oil, cheese butter, nicotinamide, and streptozotocin. This research was used the laboratory glassware, rotary evaporator, oven, UV Visible spectrophotometer, the homeostasis model assessment of insulin resistance (HOMA-IR), glucometer, syringe, sonde, experimental animal cage, and mixer.

\section{Sample Preparation}

Chayote squash is cleaned from impurities and cut into small pieces, and dried in a drying cabinet with a temperature of $\pm 50^{\circ} \mathrm{C}$. It was then mashed into a powder dried simplicia squash.

\section{Simplicia Characteristics Examination}

Examination conducted to the squash includes macroscopic analysis, determination of water content, determination of water-soluble extracts, determination of ethanol-soluble extracts, determination of total ash content, and determination of ash content insoluble in acid. ${ }^{18,19}$

\section{Determination of Water Content}

The water content was determined by the Azeotropic method (toluene distillation). The device consisted of a $500 \mathrm{ml}$ round bottom flask, a cooler, a connecting tube, a $5 \mathrm{ml}$ scale accepting tube of $0.05 \mathrm{ml}$, a reservoir, and an electric heater. The simplicia moisture content was determined by carefully placed a total of $5 \mathrm{~g}$ of weighed Simplicia powder into a flask containing saturated toluene and was heated for 15 minutes. After the toluene boils, the droplet speed was set to 2 drops per second until most of the water was distilled. The distillation speed was increased to 4 drops per second. After all the water was purified, the inside of the cooler was rinsed with toluene. The distillation was conducted for another five minutes, and the receiver tube was cooled to room temperature. After the water and toluene were completely separated, the volume of water was read to the accuracy of $0.05 \mathrm{ml}$. Water content was calculated in percentage. ${ }^{19}$ 


\section{Determination of Water Soluble Extract Content}

A total of $5 \mathrm{~g}$ of simplicia powder was macerated for 24 hours with $100 \mathrm{ml}$ of water-chloroform $(2.5 \mathrm{ml}$ of chloroform in distilled water to $1 \mathrm{~L}$ ) in a round bottom flask. It was occasionally beaten for the first 6 hours, then left for 18 hours, and filtered. The first $20 \mathrm{ml}$ of the filtrate was evaporated to dryness in a flat bottom evaporating cup that has been heated and tamed. The remainder was heated at $105^{\circ} \mathrm{C}$ until the weight remains. The content in percent water-soluble extracts is calculated against the dried material. ${ }^{18}$

\section{Determination of Ethanol Soluble Extract Content}

A total of $5 \mathrm{~g}$ of simplicia powder was macerated for 24 hours in $100 \mathrm{ml}$ of $96 \%$ ethanol inside of a round bottom flask and occasionally shaken for the first 6 hours. It was then left for 18 hours and quickly filtered afterward to avoid the evaporation of ethanol. An amount of $20 \mathrm{ml}$ of filtrate was evaporated to dryness in a flat bottom evaporating cup that has been heated and tamed. The remainder was heated at $105^{\circ} \mathrm{C}$ until the weight was constant. The percentage of extract soluble in ethanol $96 \%$ was calculated from the dried material. ${ }^{18}$

\section{Determination of Total Ash Content}

A total of $2 \mathrm{~g}$ of crushed powder was carefully put in porcelain crucibles, tiled, then flattened. Crushes slowly incandescent until the charcoal runs out, the incandescent was carried out at $600^{\circ} \mathrm{C}$ for 3 hours. It was then cooled and weighed until a fixed weight was obtained. Ash content was calculated from the dried material. $^{18}$

\section{Determination of Acid-insoluble Ash Content}

Ash obtained in the determination of total ash content was boiled in $25 \mathrm{ml}$ of dilute hydrochloric acid for 5 minutes. The insoluble part of the ash was collected, filtered through ash-free filter paper, washed with hot water, incanted to a fixed weight, then cooled and weighed. The content of acid-insoluble ash in the dried material was calculated. ${ }^{18}$

\section{Chayote Squash Extraction and Fractionation}

Simplicia powder of chayote squash was macerated with $80 \%$ ethanol solvent. ${ }^{18}$ The macerate obtained was evaporated with the help of a rotary evaporator at $\pm 40^{\circ} \mathrm{C}$ until a thick extract formed. The extract yield values obtained were calculated: ${ }^{20}$

Yield extract $\%=\mathrm{W} 1 / \mathrm{W} 0 \times 100 \%$

$\mathrm{W} 1=$ extract weight and $\mathrm{W} 0=$ total simplicia before extraction.

The fractionation was proceeded by adding $50 \mathrm{ml}$ of $96 \%$ ethanol and $100 \mathrm{ml}$ of hot water to the thick extract in a separating funnel. It was then extracted with $100 \mathrm{ml}$ of ethyl acetate until the aqueous layer gave positive results with $\mathrm{FeCl}_{3}$ reagent, which means that the ethyl acetate fraction is produced. The ethyl acetate solvent was evaporated with a rotary evaporator at a temperature of $\pm 40^{\circ} \mathrm{C}$.

\section{Phytochemical Screening}

Phytochemical screenings of ethanol extract and ethyl acetate fraction of chayote squash include the examination of compounds of alkaloid, flavonoid, glycoside, tannin, saponin, and steroid/ triterpenoid. ${ }^{18}$

\footnotetext{
Alkaloid Examination

The ethanol and ethyl acetate fraction of the chayote squash were weighed as much as $0.5 \mathrm{~g}$ then mixed with $1 \mathrm{ml}$ of $2 \mathrm{~N}$ hydrochloric acid and $9 \mathrm{ml}$ of distilled water. It was then heated on a water bath for 2 minutes, cooled, and filtered. The filtrate obtained was used for the alkaloid test, in which 3 test tubes were taken, and $0.5 \mathrm{ml}$ of filtrate was added. In each test tube, a different reagent was added. About two drops of Mayer reagent was added to test tube I, two drops of Bouchard at reagent into test tube II, and two drops of Dragendorf reagent into test tube III. ${ }^{18}$ Alkaloids are positive if sediment or turbidity has occurred in at least two of the three trials above. ${ }^{18}$
} 


\section{Flavonoid Examination}

A total of $10 \mathrm{~g}$ of ethanol extract and ethyl acetate fraction of the chayote squash were mixed with $100 \mathrm{ml}$ of boiling water, boiled for 5 minutes, and filtered under heat. About $5 \mathrm{ml}$ of the filtrate obtained was taken and combined with $0.1 \mathrm{~g}$ of magnesium powder, $1 \mathrm{ml}$ of hydrochloric acid, and $2 \mathrm{ml}$ of amyl alcohol, shaken and then separated. Flavonoids are stated "positive" if there is a red, yellow, orange color in the amyl alcohol layer. ${ }^{21}$

\section{Glycoside Examination}

The ethanol and ethyl acetate fraction of the chayote squash were weighed as much as $3 \mathrm{~g}$, then filtered with $30 \mathrm{ml}$ of $95 \%$ ethanol mixed with water $(7: 3)$ and $10 \mathrm{ml}$ of hydrochloric acids $2 \mathrm{~N}$, refluxed for 2 hours, cooled, and filtered. $20 \mathrm{ml}$ of the filtrate were added with $25 \mathrm{ml}$ of lead (II) acetate $0.4 \mathrm{M}$ and shaken with $25 \mathrm{ml}$ of distilled water, then allowed to stand 5 minutes, and filtered. The filtrate was filtered with 20 $\mathrm{ml}$ of a mixture of isopropanol and chloroform (2:3), repeated three times. The juice was collected and evaporated at a temperature of no more than $50^{\circ} \mathrm{C}$. The remainder was dissolved in $2 \mathrm{ml}$ methanol. The remaining solution was used for the following experiment. About $0.1 \mathrm{ml}$ of the test solution was put in a test tube and evaporated on a water bath. Two $\mathrm{ml}$ of water and five drops of Molisch reagent were added to the remaining. About $2 \mathrm{ml}$ of concentrated sulfuric acid through the tube wall, the formation of a purple ring between the two liquids indicates the bond of sugar. ${ }^{18}$

\section{Tannin Examination}

A total of $1 \mathrm{~g}$ of ethanol extract and ethyl acetate fraction of chayote squash was filtered with $10 \mathrm{ml}$ of distilled water. The filtrate was mixed with distilled water until it was colorless. The solution was taken as much as $2 \mathrm{ml}$ and added 1-2 drops of 1\% iron (III) chloride reagent. The presence of tannins was indicated by the blackish-blue or blackish green or blue or green color. ${ }^{22}$

\section{Saponin Examination}

$0.5 \mathrm{~g}$ of ethanol extract and ethyl acetate fraction of chayote squash was added to the test tube with $10 \mathrm{ml}$ of hot water, cooled, and then shaken for ten ethics. If a stable $1-10 \mathrm{~cm}$ stable foam is formed not less than 10 minutes and does not change with the addition of one drop of hydrochloric acids $2 \mathrm{~N}$ indicates the presence of saponins. ${ }^{18}$

\section{Steroid/Steroid Examination}

A total of $1 \mathrm{~g}$ of ethanol extract and ethyl acetate fraction of chayote squash was macerated with $20 \mathrm{ml}$ ether for 2 hours. Then the macerate obtained was filtered, then the filtrate is evaporated in a vaporizer cup, and the remaining ten drops of anhydrous acetic acid and one drop of concentrated sulfuric acid (Lieberman Burchard reagent) were added. If the greenish-blue or purple-red color is formed, it indicates the presence of steroids/triterpenoids contained in the simplicia or extract. ${ }^{22}$

\section{Testing of Total Flavonoid Levels}

The sample solution was prepared by weighing the extract as much as $50.0 \mathrm{mg}$ and later dissolving it with methanol p.a. up to $5 \mathrm{ml}$. About $0.2 \mathrm{ml}$ sample solution was taken, and $1.5 \mathrm{ml}$ ethanol pa, $0.1 \mathrm{ml} 10 \%$ ammonium chloride, $0.1 \mathrm{ml}$ potassium acetate $1 \mathrm{M}$ were added. Aqua distillate to $5.0 \mathrm{ml}$ was added, and the mixture was then incubated in room temperature for 23-27 minutes and read at a wavelength of $427 \mathrm{~nm}$. Quercetin standard curves were made with concentrations of $1,5,10,15$ and $20 \mu \mathrm{g} / \mathrm{ml}$. Results are stated as $\mathrm{QE}$ (quercetin equivalent)/ g extract. ${ }^{9}$

\section{Testing the Total Phenol Levels}

The sample solution was made by taking $0.1 \mathrm{ml}$ of a concentration of $10 \mathrm{mg} / \mathrm{ml}$ then adding methanol p.a. up to $1 \mathrm{ml}$ and then as much as $0.2 \mathrm{ml}$ sample solution mixed with $0.5 \mathrm{ml}$ of Folin-Ciocalteu reagents then incubated for 5 minutes and added $4 \mathrm{ml}$ of $\mathrm{Na}_{2} \mathrm{CO}_{3}$ solution $1 \mathrm{M}$ add $10 \mathrm{ml}$ of aqua distillate then incubated for 33-37 minutes and read at length wave $756.5 \mathrm{~nm}$. Gallic acid standard curves were made with concentrations of $0.5,2.5,5,7.5$, and $10 \mu \mathrm{g} / \mathrm{ml}$. Results are stated as GAE (gallic acid equivalent)/ g extract. $^{3}$ 
Vol. 14 | No. 1 |65-73| January - March | 2021

Insulin Function Profile and Blood Glucose Level

Experimental animals in each treatment consisted of 4 male albino rats in each group. Based on Federer's calculations, the treatment in this study consisted of 11 groups namely;

a. Group A; negative control (normal), untreated, like normal mice in general who were given excessive food and drink (ad libitum).

b. Group B; positive control, induced with streptozotocin $45 \mathrm{mg} / \mathrm{kg} \mathrm{bw}+$ nicotinamide $110 \mathrm{mg} / \mathrm{kg}$ bw + HFD

c. Group C; positive control, induced with streptozotocin $45 \mathrm{mg} / \mathrm{kg}$ bw + HFD

d. Group D; positive control, induced with nicotinamide $110 \mathrm{mg} / \mathrm{kg}$ bw + HFD

e. Group E; administered with ethanol extract of chayote squash $45 \mathrm{mg} / \mathrm{kg}$ bw, p.o

f. Group F; administered with ethanol extract of chayote squash $100 \mathrm{mg} / \mathrm{kg}$ bw, p.o.

g. Group G; administered with ethanol extract of chayote squash $150 \mathrm{mg} / \mathrm{kg}$ bw, p.o.

h. Group H; administered with ethyl acetate fraction of chayote squash $45 \mathrm{mg} / \mathrm{kg} \mathrm{bw}$, p.o.

i. Group I; administered with ethyl acetate fraction of $100 \mathrm{mg} / \mathrm{kg}$ bw chayote squash, p.o.

j. Group J; administered with ethyl acetate fraction of chayote squash $150 \mathrm{mg} / \mathrm{kg} \mathrm{bw}$, p.o.

k. Group K; administered with metformin $40.5 \mathrm{mg} / \mathrm{kg}$ bw, p.o

In the first stage, the experimental rats are induced with a high-fat diet (HFD), which aims to cause insulin resistance. The high-fat diet used consists of a mixture of quail egg yolks, coconut oil, and butter in a ratio of 1: 6: 3. HFD induction treatment was given as much as $4 \mathrm{ml}$ in mice every day orally. In the second stage, the experimental rats were induced hyperglycemic using nicotinamide at a dose of $110 \mathrm{mg} / \mathrm{kg}$ bw and streptozotocin $45 \mathrm{mg} / \mathrm{kg}$ bw intraperitoneally (i.p) every day for 30 days. Testing animals were diagnosed with diabetes mellitus when blood glucose levels $>250 \mathrm{mg} / \mathrm{dl}$ after 72 hours of induction. ${ }^{23,16}$ The treatment was carried out every day for 28 days at the same time to control the occurrence of different metabolic times. Tests carried out in each treatment include measurements of normal glucose levels (H0), initial blood glucose levels were induced $\left(\mathrm{H}_{1}\right)$, and final blood glucose levels $\left(\mathrm{H}_{28}\right)$. It also tested load glucose (LG), fasting blood glucose $\left(\mathrm{H}_{28}\right)$, insulin levels, and HOMA-B levels.

\section{Simplicia Powder Characteristics}

\section{RESULTS AND DISCUSSION}

The simplistic characteristic examination includes the determination of total ash content, acid insoluble ash content, water content, water-soluble extract, and ethanol-soluble extract. The characteristics of simplicia are presented in Table-1.

Table-1: Simplicia Characteristics of the Chayote Squash

\begin{tabular}{c|c}
\hline Parameter & Result \\
\hline Total Ash Content, \% & 8.42 \\
\hline Acid Soluble Ash Levels, \% & 1.15 \\
\hline Water content, \% & 8.66 \\
\hline Water Soluble Extract Content, \% & 89.28 \\
\hline Ethanol Soluble Extract Content, \% & 97.82 \\
\hline
\end{tabular}

The macroscopic characteristics of fresh chayote fruit were green to yellowish-green color, and curved surface with longitudinal grooves. The results of the simplicia test of the chayote have a drying shrinkage level of $90.47 \%$, moisture content of $93.69 \%$, a total ash content of $0.44 \%$, an acid insoluble ash content of $0.02 \%$, a water-soluble extract and soluble extract ethanol of $0.52 \%$ each. The content of simplicia of the chayote squash, total ash, acid-insoluble ash, water-soluble extract, and ethanol-soluble extract was $8.66 \%, 8.42 \%, 1.15 \%$, $89.28 \%$, and $97.82 \%$, respectively. The result shows that the simplicia moisture content is following the quality standards. That simplicia has a moisture content of less than $10 \%$, at which microbial growth that might reduce the stability of extract quality can be prevented. ${ }^{18,24}$ The quality stability of the extract is accordingly optimal. 
Total ash content describes the mineral content contained in a plant both from inside and outside during the manufacture of extracts. The value of total ash content indicates purity and contamination. ${ }^{25}$ The higher the total ash content, the higher the mineral content, the higher the total ash content. Likewise, acid insoluble ash levels indicate mineral contamination of silica acids or metals containing silica such as soil and sand, metal elements mercury, silver, and lead. ${ }^{12,13}$ Water-soluble extract and ethanol-soluble extract indicate that compound from chayote is less water-soluble than ethanol. Polar compounds contained in chayote are less than non-polar compounds. Determination of water-soluble and ethanol extract content is intended as a rough estimate of the content of active compounds that are polar (water-soluble) and active compounds that are semi polar-nonpolar (soluble ethanol). ${ }^{13,24}$

\section{Yield Extraction Rate}

The yield is the ratio of extracts obtained and dried simplicia. From 12,120 kg of simplicia powder obtained, $2,024 \mathrm{~kg}$ of the thick extract have a yield value of $16.69 \%$. The yield content is better when compared to the research of Firdous et al. ${ }^{24}$, at which the highest yield was $2.40 \%$. These results indicate that little simplicia powder will relatively be extracted. The yield value can be affected by the extraction method, temperature, comparison of the number of samples and the amount of solvent, the type of solvent and the extraction time. ${ }^{17,26,27}$

\section{Phytochemical Screening}

Secondary metabolites in chayote are extracted using solvents with different polarities so that the active compounds can be extracted according to the level of solubility. The secondary metabolite compounds found in ethanol extract and ethyl acetate fraction can be seen in Table-2.

Table-2: Phytochemical Screening Results of the Chayote Squash

\begin{tabular}{c|c|c}
\hline \multicolumn{3}{c}{ Table-2: Phytochemical Screening Results of the Chayote Squash } \\
\hline Secondary Metabolites & Ethanol Extract & Ethyl Acetate Faction \\
\hline Alkaloid & + & + \\
\hline Flavonoid & + & + \\
\hline Glycoside & + & + \\
\hline Saponin & + & + \\
\hline Tannin & + & + \\
\hline Triterpenoid/Steroid & + & - \\
\hline
\end{tabular}

$+:$ there are classes of compounds

- : no compound found

Table two illustrates that ethanol extract and ethyl acetate fraction containing alkaloids, flavonoids, glycosides, saponins, and tannins, but only ethanol extracts contain steroids. Phytochemical screening of chayote shows that ethanol as a polar solvent can attract active polymers and non-polar secondary metabolites such as alkaloids, flavonoids, glycosides, saponins, tannins, triterpenes/ steroids, while ethyl acetate fractions which are semi-polar solvents are not capable of attracting triterpenes/steroids. According to Hossain et al ${ }^{28}$, ethanol solvents are the best solvents for dissolving polyphenols such as tannins. The composition in a screening can be different from the others, although the plants used are the same depending on the type of extraction used, extraction time, temperature, solvent nature, and solvent concentration. ${ }^{15,29,30}$

\section{Total Flavonoid Levels and Total Phenols}

The total phenolic content and total flavonoid ethanol extract of chayote squash are presented in Table-3.

Table-3: Total Flavonoids and Total Phenolic

\begin{tabular}{c|c|c}
\hline Sample & Total Flavonoid & Total Phenolic \\
\hline Ethanol Extract & $3.37 \mathrm{~g} / 100 \mathrm{~g}$ & $1,977.10 \mathrm{mg} \mathrm{GAE} / 100 \mathrm{~g}$ \\
\hline Ethyl Acetate Faction & $7.05 \mathrm{~g} / 100 \mathrm{~g}$ & $1,344.88 \mathrm{mg} \mathrm{GAE} / 100 \mathrm{~g}$ \\
\hline
\end{tabular}


Based on the table above, the highest total flavonoid content was found in the ethyl acetate fraction, which was $7.05 \mathrm{~g} / 100 \mathrm{~g}$. Meanwhile, the highest phenolic total was found in ethanol extract of 1,977.10 mg GAE/ $100 \mathrm{~g}$. Total phenolic levels are higher than total flavonoid levels, as flavonoids are also part of phenolic compounds. Ethanol extract has higher total phenolic levels on account of the ability of ethanol extract in attracting polyphenols. ${ }^{14,28}$ This study is also following Volluri et al. ${ }^{10}$ at which the total phenolic level is higher when compared to the total flavonoids. Nevertheless, there are differences in the levels of each extract due to differences in the growth place for each sample of squash. Phenols and flavonoids act as antioxidants by donating hydrogen atoms to free radicals. ${ }^{31}$ Clinically, polyphenol compounds such as flavonoids, phenolic acids, and tannins play a role in inhibiting $\alpha$-glucosidase and $\alpha$-amylase, the main enzymes in the digestion of carbohydrates into glucose. ${ }^{6,32}$

Testing of Insulin Function Profiles and Blood Glucose Levels.

Profiles of insulin function and blood glucose levels are presented in Table-4.

Table-4: Examination of Blood Glucose (BG), Load Glucose (LG), Insulin and HOMA-B

\begin{tabular}{|c|c|c|c|c|c|c|c|}
\hline \multirow[b]{2}{*}{ Group } & \multicolumn{7}{|c|}{ Examination } \\
\hline & $\begin{array}{l}\text { Normal } \\
\text { Blood } \\
\text { Glucose }\end{array}$ & $\begin{array}{l}\text { BG Initial } \\
\text { Induction }\end{array}$ & $\begin{array}{l}\text { Blood Glucose } \\
\text { End Action }\end{array}$ & $\begin{array}{l}\text { Load } \\
\text { Glucose }\end{array}$ & $\begin{array}{l}\text { Fasting Blood } \\
\text { Glucose }\end{array}$ & INSULIN & $\begin{array}{l}\text { HOMA- } \\
\text { B }\end{array}$ \\
\hline A & $101.50 \pm 4.50$ & $124.00 \pm 3.00$ & $126.50 \pm 1.50$ & $-2.04 \pm 1.26$ & $186.38 \pm 9.70$ & $4.08 \pm 0.72$ & $0.44 \pm 0.56$ \\
\hline B & $107.67 \pm 13.38$ & $262.00 \pm 6.93$ & $143.67 \pm 25.18$ & $45.59 \pm 8.15$ & $215.57 \pm 53.80$ & $2.53 \pm 1.32$ & $0.19 \pm 0.86$ \\
\hline $\mathrm{C}$ & $113.00 \pm 1.73$ & $256.00 \pm 3.05$ & $287.00 \pm 44.60$ & $40.32 \pm 30.80$ & $413.09 \pm 115.84$ & $4.64 \pm 2.19$ & $0.18 \pm 0.08$ \\
\hline $\mathrm{D}$ & $109.33 \pm 1.76$ & $255.67 \pm 4.25$ & $109.33 \pm 6.12$ & $57.14 \pm 2.96$ & $276.69 \pm 35.99$ & $5.02 \pm 2.3$ & $0.34 \pm 0.16$ \\
\hline $\mathrm{E}$ & $108.75 \pm 4.31$ & $411.50 \pm 71.41$ & $150.75 \pm 57.62$ & $64.68 \pm 8.35$ & $155.16 \pm 15.96$ & $0.44 \pm 0.12$ & $0.10 \pm 0.02$ \\
\hline $\mathrm{F}$ & $117.00 \pm 7.67$ & $401.25 \pm 54.68$ & $253.25 \pm 74.18$ & $39.58 \pm 12.74$ & $167.06 \pm 12.17$ & $6.87 \pm 0.49$ & $0.86 \pm 0.10$ \\
\hline G & $98.25 \pm 10.92$ & $354.00 \pm 59.96$ & $99.75 \pm 11.71$ & $69.82 \pm 5.17$ & $187.18 \pm 27.28$ & $3.87 \pm 1.20$ & $0.48 \pm 0.17$ \\
\hline $\mathrm{H}$ & $117.25 \pm 6.07$ & $383.75 \pm 19.35$ & $283.75 \pm 105.08$ & $25.78 \pm 27.97$ & $229.58 \pm 14.96$ & $6.14 \pm 0.35$ & $0.55 \pm 0.06$ \\
\hline I & $93.25 \pm 13.96$ & $459.00 \pm 61.56$ & $101.25 \pm 4.76$ & $76.37 \pm 3.96$ & $163.12 \pm 7.308$ & $3.77 \pm 1.21$ & $0.49 \pm 0.17$ \\
\hline $\mathrm{J}$ & $105.25 \pm 9.19$ & $335.00 \pm 54.59$ & $163.25 \pm 47.45$ & $52.45 \pm 8.20$ & $278.08 \pm 28.37$ & $4.71 \pm 1.69$ & $0.34 \pm 0.11$ \\
\hline K & $132.00 \pm 14.66$ & $379.75 \pm 42.23$ & $130.25 \pm 11.01$ & $63.25 \pm 7.41$ & $150.54 \pm 8.61$ & $4.58 \pm 1.84$ & $0.61 \pm 0.23$ \\
\hline $\mathrm{p}$ - value & $0.370^{*}$ & $0.003 *$ & $0.087^{*}$ & $0.017 *$ & 0.001 & 0.12 & 0.01 \\
\hline $\begin{array}{l}\text { Note: } \\
\text { *ANOVA t } \\
\text { A: Negative } \\
\text { B: Positive } \\
\text { C: Positive } \\
\text { D: Positive } \\
\text { E: Ethanol } \\
\text { F: Treatmer } \\
\text { G: Ethanol } \\
\text { H: Treatme } \\
\text { I: Treatmer } \\
\text { A: Ethyl ac } \\
\text { K: Metform }\end{array}$ & $\begin{array}{l}\text { st } \\
\text { control (normal), } \\
\text { ontrol, induced S } \\
\text { ontrol, induced } \mathrm{S} \\
\text { control, induced } n \\
\text { xtract squash } 45 \mathrm{n} \\
\text { t group of ethanol } \\
\text { xtract chayote squ } \\
\text { it group of ethyl a } \\
\text { t group of ethyl ac } \\
\text { tate fraction treatı } \\
\text { in treatment group }\end{array}$ & $\begin{array}{l}\text { treptozotocin } 50 \mathrm{n} \\
\text { treptozotocin } 45 \mathrm{n} \\
\text { icotinamide } 110 \mathrm{n} \\
\mathrm{ng} / \mathrm{kg} \text { bw, p.o. } \\
\text { extract of chayot } \\
\text { uash } 150 \mathrm{mg} / \mathrm{kg} \mathrm{b} \\
\text { cetate fraction of } \\
\text { cetate fraction of } 1 \\
\text { ment group of cha } \\
40.5 \mathrm{mg} / \mathrm{kg} \mathrm{bw}\end{array}$ & $\begin{array}{l}\mathrm{ng} / \mathrm{kg} \text { bw }+ \text { nicotin } \\
\mathrm{ng} / \mathrm{kg} \mathrm{bw}+\mathrm{HFD}, \\
\mathrm{ng} / \mathrm{kg} \mathrm{bw}+\mathrm{HFD} \text {, } \\
\text { e squash } 100 \mathrm{mg} / \mathrm{k} \\
\text { w, p.o. } \\
\text { chayote squash } 45 \\
100 \mathrm{mg} / \mathrm{kg} \text { bw chas } \\
\text { yote squash } 150 \mathrm{~m}\end{array}$ & $\begin{array}{l}\text { amide (120 mg/ } \\
\text { g bw, p.o. } \\
\text { mg/kg bw, p.o. } \\
\text { ote squash, p.o. } \\
\text { g/kg bw, p.o., }\end{array}$ & & & \\
\hline
\end{tabular}

Based on the data above, the group that experienced the highest decrease in blood sugar levels was in group I, given $100 \mathrm{mg} / \mathrm{kg}$ bw of ethyl acetate fraction. The p-value showed differences between each treatment 
group. The group that had high insulin and good B-cell function were found in group F, which were given ethanol extract $100 \mathrm{mg} / \mathrm{kg}$ bw p.o. with a value of $\mathrm{p}>0.05$, which means there are no significant differences between groups. Testing the value of HOMA-B has a value of $p<0.05$, indicating a difference between treatment groups. Glucose reduction was best found in the group that received $100 \mathrm{mg} / \mathrm{kg}$ bw of ethyl acetate fraction with a $\mathrm{p}$-value $<0.05$.

The hypoglycemic effect of ethyl acetate fraction is caused by flavonoids, alkaloids, triterpene, glycosides, and saponins, which result in the accumulation of glycogens through glycogen synthetase, which is stimulated by insulin secretion. ${ }^{33}$ The total performance of phenolic and flavonoids in reducing blood sugar levels by prolonging carbohydrate digestion time and inhibiting the absorption of carbohydrates in the intestine, stimulating insulin secretion and increasing glucose transport into cells. ${ }^{34,35,36,37}$ Impaired absorption in the small intestine through sodium-dependent glucose transporter 1 (SGLT1) can stimulate insulin secretion and reduce liver glucose. The use of polyphenol compounds also accelerates the transport of glucose by insulin, 5' AMP-activated protein kinase (AMPK), modifies the microbiome and has antiinflammatory properties. ${ }^{35}$ The role of flavonoids has a direct effect on the insulin signaling pathway, which can increase insulin sensitivity by inducing IR and IRS phosphorylation and activating the PI3K/Akt Pathway, AMPK expression, GLUT4 translocation of muscle cells and adipocyte cells, decreasing PEPCK and G6P expression, suppressing gluconeogenesis and increasing expression GK and GSK, encourage glycogen synthesis. ${ }^{38}$

Pancreatic $\beta$ cell function can be assessed by HOMA-B using the formula: HOMA1- $\% \mathrm{~B}=(20 \times$ FPI $) /$ (FPG - 3.5) for IR and $\beta$-cell functions, respectively, where FPI is fasting plasma insulin concentration $(\mathrm{mU} / \mathrm{l})$, and FPG is fasting plasma glucose $(\mathrm{mmol} / \mathrm{l}){ }^{39}$ The group was received $100 \mathrm{mg} / \mathrm{kg}$ bw ethanol extract had good insulin secretion and had a good pancreatic $\beta$-cell function. This effect is caused by flavonoids that are protective against pancreatic $\beta$-cells by inhibiting pancreatic $\beta$-cell degeneration through reducing oxidative stress caused by glucotoxicity, lipotoxic and increasing mitochondrial bioenergy. ${ }^{40}$

\section{CONCLUSION}

In this study, it can be concluded that the chayote squash contains secondary metabolites compound, which can work actively on pancreatic B-cell function and decrease blood glucose levels. The treatment of 100 $\mathrm{mg} / \mathrm{kg}$ bw of ethanol extract of chayote squash containing total phenol levels $1977.10 \mathrm{mg}$ GAE $/ 100 \mathrm{~g}$ was proven to stimulate insulin secretion while being protection against pancreatic B-cells. Administration of $100 \mathrm{mg} / \mathrm{kg}$ bw of ethyl acetate fraction with a content of $7.05 \mathrm{~g} / 100 \mathrm{~g}$ of total flavonoids, meanwhile, could reduce glucose levels in the blood.

\section{REFERENCES}

1. American Diabetes Association, Diagnosis and Classification of Diabetes Mellitus, Diabetes Care, 31(1), S55(2008), DOI:10.2337/dc08-S055

2. A. Amod, A. Coetzee, T. E. Kinvig, I. Paruk, Z. Bayat, J. A. Dave, Journal of Endocrinology, Metabolism and Diabetes of Southern Africa, 22(1), S1(2017), DOI: 10.13140/RG.2.2.29645.90083

3. K. Ghasemi, Y. Ghasemi, and M.A. Ebrahimzadeh, Pakistan Journal of Pharmaceutical Sciences., 22(3), 277(2009).

4. A. Ghorbani, R. Rashidi, and R. Shafiee-Nick, Biomedicine \& Pharmacotherapy, 111, 947 (2019), DOI:10.1016/j.biopha.2018.12.127

5. $\quad$ K. Kohei, Japan Medical Association Journal, 53(1), 41(2010).

6. D. Lin, M. Xiao, J. Zhao, Z, Li, B. Xing, X. Li, and S. Chen, Molecules, 21(10), 1374(2016), DOI: $10.3390 /$ molecules21101374

7. J. M. Siahaan, Indonesian Journal of Medicine., 2(2), 86(2017).

8. H. Lei, J. Han, Q, Wang, S. Guo, H. Sun, and X. Zhang, International Journal of Molecular Sciences, 13, 16961(2012), DOI:10.3390/ijms131216961

9. C. C. Chang, M. H. Yang, H. M. Wen, and J. C. Chern, Journal of Food and Drug Analysis, 10 (3), 178(2002), DOI:10.38212/2224-6614.2748

10. S. S. Volluri, S.R. Bammidi, S.C. Chippada, and M. Vangalapati, Rasayan Journal Chemistry, 4(2), 381(2011).

11. D. Porte, and S.E. Kahn, Diabetes, 50(1), S160-3, DOI:10.2337/diabetes.50.2007.S160

12. S.L. Deore, and S.S. Khadabadi, Rasayan Journal Chemistry, 1(4), 887(2008). 
Vol. 14 | No. 1 |65-73| January - March | 2021

13. L. Kishore, A. Kajal, and N. Kaur, Journal of Endocrinology and Thyroid Research, 2(1), 1(2017), DOI:10.19080/JETR.2017.02.555577

14. R. Y. Gan, C. L. Chan, Q. Q. Yang, H. B. Li, D. Zhang, Y. Y Ge, and H. Corke, Sprouted Grains, 2019, 191(2019), DOI:10.1016/b978-0-12-811525-1.00009-9

15. A. Mathur, R. Bhat, G.B.K.S. Prasad, V.K. Dua, S.K. Verma, and P.K. Agarwal, Rasayan Journal Chemistry, 3(4), 615(2010).

16. A. Pandey, and S. Tripathi, Journal of Pharmacognosy and Phytochemistry, 2(5), 115(2014).

17. L. Pari, K. Karthikesan, and V. P Menon, Molecular and Cellular Biochemistry, 341, 109(2010), DOI: $10.1007 / \mathrm{s} 11010-010-0442-5$

18. S. Pooja, and G.M, Vidyasar, Journal of Medicinal Plants Studies, 4(5), 39(2016).

19. Ditjen POM, Farmakope Indonesia, Edisi IV, Jakarta: Departemen Kesehatan RI. (1995)

20. World Health Organization, Quality Control Methods for Medical Plant Materials, Switzerland, World Health Organization, pp.31-33 (1998).

21. S. C. Mandal, V. Mandal, and A. K. Das, Essentials of Botanical Extraction: Principles and Applications, Elsevier, pp.81 (2015).

22. N. R. Farnsworth, Journal of Pharmaceutical Sciences, 55(3), 225(1996).

23. J. B. Harborne, Phytochemical Methods: A Guide to Modern Techniques of Plant Analysis, $2^{\text {nd }}$ Edition (1984), DOI:10.1007/978-94-009-5570-7

24. S. M. Firdous, and A. Singh, Asian Pacific Journal of Health Sciences, 3(3), 30(2016), DOI:10.21276/apjhs.2016.3.3.6

25. Y. Rao, and B. Xiang, Yakugaku Zasshi, 129(7), 881(2009), DOI:10.1248/yakushi.129.881

26. Depkes RI, Parameter Standar Umum Ekstrak Tumbuhan Obat, Departemen Kesehatan Republik Indonesia, Jakarta, Indonesia (2000).

27. A. E. Erviani, and A. R. Arif, International Journal of Current Research and Academic Review, 5(11), 25(2017).

28. M.B. Hossain, N.P. Brutton, C. Barry-Ryan, A.B. Martin-Diana, and M. Wilkinson, Rasayan Journal Chemistry, 1(4), 751(2008).

29. Q. D. Do, A. E. Angkawijaya, P. L. Tran-Nguyen, L. H. Huynh, F. E. Soetardjo, S Imadji, and Y. H. Ju, Journal of Food and Drug Analysis, 22(3), 296(2014), DOI:10.1016/j.jfda.2013.11.001

30. P. Tiwari, B. Kumar, and M. Kaur, Internationale Pharmaceutica Sciencia, 1(1), (2011).

31. S. Velavan, World Journal of Science and Research, 1(2), 80(2015).

32. S. Aryal, M. K. Baniya, K. Danekhu, P. Kunwar, R. Gurung, and N. Koirala, Plants, 8(4), 96(2019), DOI: 10.3390/plants8040096

33. B. Bakoma, B. Berke, K. E. Gadegbeku, K. Diallo, A. Agbono, K. Aklikokou, M. Gbeassor, and N. Moore, Research Journal of Phytochemistry, 6(4), 120(2012), DOI:10.3923/rjphyto.2012.120.126

34. C. R. Hancock, D. H. Han, M. Chen, S. Terada, T. Yasuda, D. C. Wright, and J. O. Holloszy, Proceedings of the National Academy of Sciences of the United States of America, 105(22), 7815(2008), DOI:10.1073/pnas.0802057105

35. H. Alkhalidy, and Y. Wang, D. Liu, Nutrients, 10(4), 438(2018), DOI:10.3390/nu10040438

36. Y. Kim, J. Keogh, and P. Clifton, Nutrients., 8(1), 17(2016), DOI:10.3390/nu8010017

37. S. Sekhon-Loodu, and H.P.V. Rupasinghe, Frontier in Nutrion, 6(53), 1(2019), DOI: $10.3389 /$ fnut.2019.00053

38. O. O. Olaokun, L. J. McGaw, I. J. V. Rensburg, N. Jacobus, J. N. Eloff, and V. Naidoo, BMC Complementary and Alternative Medicine, 16(110), 1(2016), DOI:10.1186/s12906-016-1087-z

39. T. M. Wallace, J. C. Levy, and D. R. Matthews, Diabetes Care, 27(6), 1487(2004), DOI: $10.2337 /$ diacare.27.6.1487

40. B. Russo, F. Picconi, I. Malandrucco, and S. Frontoni, International Journal of Molecular Sciences, 20(9), 2061(2009), DOI:10.3390/ijms20092061

[RJC-5973/2020] 